\title{
Garnet-sillimanite bearing gneisses from Darjeeling, eastern Himalaya: Textural relationship and $\mathrm{P}-\mathrm{T}$ conditions
}

\author{
Divya Prakash* and Suparna TeWARI \\ Centre of Advanced Study in Geology, Banaras Hindu University, Varanasi 221 005, India. \\ ${ }^{*}$ Corresponding author.e-mail: dprakashbhu@yahoo.com;dprakash_vns@rediffmail.com
}

The area around Darjeeling consists of medium grade metamorphic rocks and provides a classic example of inverted Himalayan metamorphism. The area under investigation shows upper amphibolite facies metamorphism (sillimanite-muscovite subfacies), rocks are intimately associated with the migmatites and granites. The presence of quartzite, calc-silicate rocks, graphitic schist and abundance of aluminous minerals like kyanite or sillimanite in these rocks indicate their metasedimentary character. Granetsillimanite bearing gneisses occupy most of the area of Darjeeling but not persistent throughout. Textural relationship suggests sequential growth of progressively higher-grade metamorphic minerals during $\mathrm{D}_{1}$ and $\mathrm{D}_{2}$ deformation. The relative $\mathrm{X}_{\mathrm{Mg}}$ in the minerals varies in the order: biotite $>$ staurolite $>$ garnet, and the $\mathrm{X}_{\mathrm{Mn}}$ decreases in the order: garnet>staurolite $>$ biotite. The $\mathrm{P}-\mathrm{T}$ evolution of these garnetsillimanite gneiss has been constrained through the use of conventional geothermobarometry, internally consistent TWEEQU programme and Perple_X software in the KFMASH model system, the combination of these three approaches demonstrates that the Darjeeling gneisses experienced peak pressure and temperature at $7.0 \pm 0.3 \mathrm{kbar}$ and $700 \pm 30^{\circ} \mathrm{C}$. The observation in this study has important bearing on the inverted metamorphism in the Himalayan metamorphic belt.

\section{Introduction}

The term 'Darjeeling Gneiss' was first used by Mallet (1875) for crystalline gneiss of Darjeeling hills of the Darjeeling Himalaya. Later this term has been used extensively by Auden (1935), Acharya (1978), Lal et al. (2005), Prakash and Tewari (2013), etc. This region constitutes a part of the lesser Himalaya and consists of metamorphic rocks belonging to Daling-Darjeeling Group (Sinha Roy 1974) of probably Precambrian to Palaeozoic age. These rocks are thrusted over younger metasedimentary rocks of Gondwana group of Permocarboniferous age towards the south, while the north these are separated from the medium to high grade rocks of the central crystalline thrust. The deformation accompanying or post-dating the thrusting movements has folded the rocks of the group in major synform (Gansser 1964). The area under investigation consists of a part of lesser Himalaya, northeastern part of India and falls between $27^{\circ} 02^{\prime} 45^{\prime \prime}$ $27^{\circ} 03^{\prime} 53^{\prime \prime} \mathrm{N}$ and $88^{\circ} 17^{\prime} 27^{\prime \prime}-88^{\circ} 21^{\prime} 08^{\prime \prime} \mathrm{E}$ in the Survey of India toposheet no.78A/8 (figure 1).

Preliminary geological mapping of the Lower Himalaya of Darjeeling were carried out by Mallet (1875), Bose (1891), Auden (1935), Heim and Gansser (1939) and others which form the base for further detailed investigations (Mukhopadhyay and Gangopadhyay 1971; Jangpangi 1972; Acharya 1978). These studies have revealed that the region has undergone multiple deformation and at least three major phases of deformation have been

Keywords. Garnet-sillimanite gneiss; textural relationship; pseudosection; P-T conditions; Darjeeling; Eastern Himalaya. 


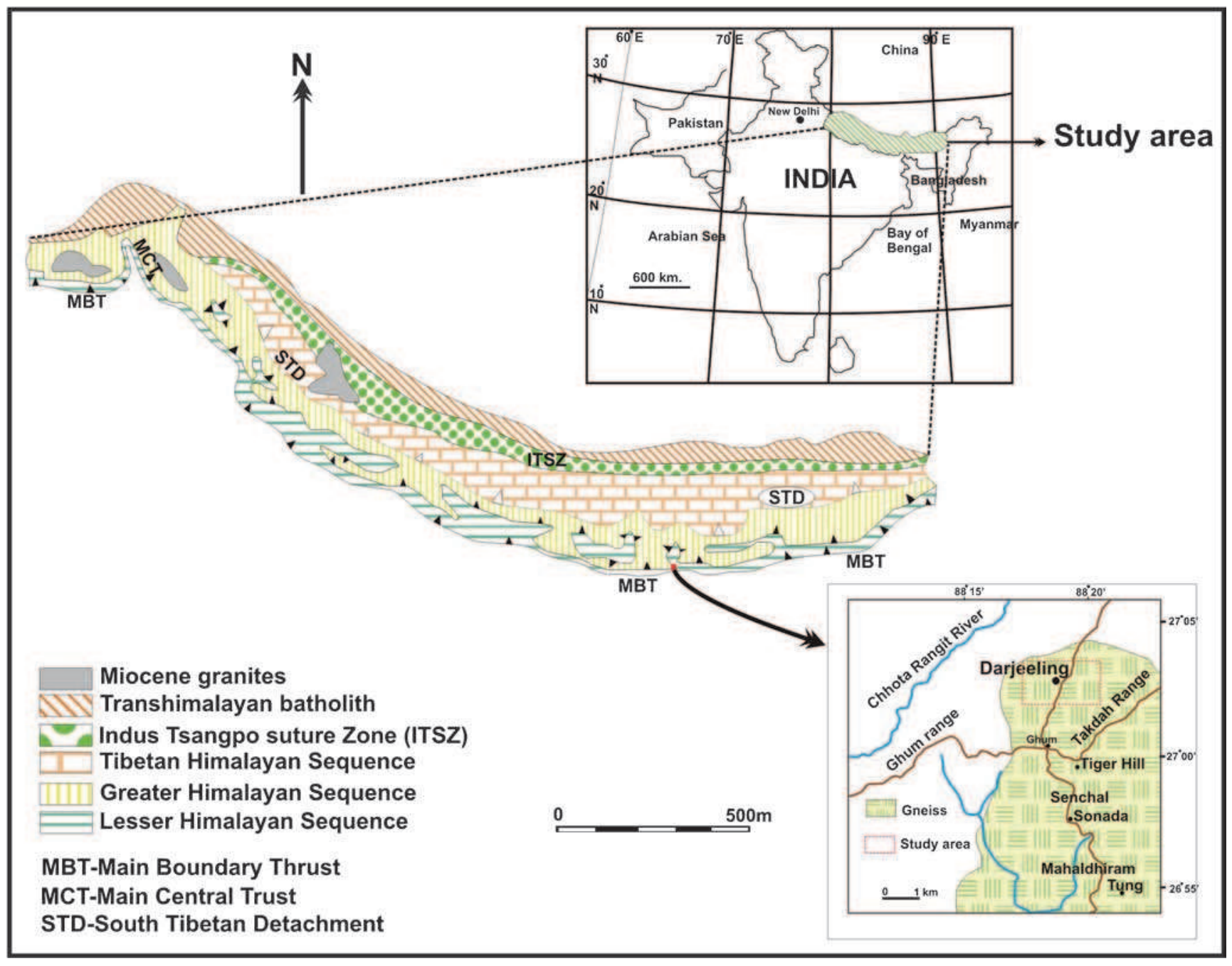

Figure 1. Generalized geological map of the Himalayas. The location of Darjeeling is shown in the box.

recognized which presumably occurred during the Tertiary Himalayan orogeny.

Isochemical phase-diagram, calculated with the thermodynamic software Perple_X (Connolly 2005) coupled with its internally consistent thermodynamic database (Holland and Powell 1998) is valid for a unique chemical composition in a model system. If it can be assumed that the analysed bulk rock composition was the effective chemical composition of the equilibrated system at the time of crystallization of garnet, the isochemical phase-diagram drawn for this composition and showing different isopleths for garnet can then be used as thermobarometric tool allowing the determination of $\mathrm{P}-\mathrm{T}$ condition. In Darjeeling-Sikkim area, number of earlier workers have provided a detailed geological and structural account (e.g., Mukul 2000; Gupta et al. 2010; Prakash and Tewari 2013), however, the metamorphic conditions of the rocks are not constrained through conventional geothermobarometers and isochemical phase-diagram approach. In this contribution, textural relationship, mineral chemistry and $\mathrm{P}-\mathrm{T}$ conditions of garnet-sillimanite bearing gneisses are presented. Furthermore, isochemical phase-diagram modelling of mineral assemblage is used to investigate the metamorphic evolution of garnet-sillimanite bearing gneisses.

\section{Geological setting and structure}

Mallet (1875), first distinguished the lithological difference in between Daling group and Darjeeling group. Wager (1939) considered Daling to be equivalent of the pelitic series of Mt. Everest, and Darjeeling gneiss to be injected at higher structural level. Gansser (1964) considered the Daling and Darjeeling to be portions of a single stratigraphic unit and divided them on the basis of their metamorphic characters and placed garnetiferous mica-schists in between them. Gansser (1964) clearly states that there is no evidence of thrusting between Daling and Darjeeling rocks particularly in the Tista valley-Darjeeling hill section. He maintains that the level of disharmonic disturbances may coincide with contact of gneiss and underlying argillaceous 
rocks in view of the difference in their respective competence. The inverted sequence of lesser Himalaya is classic itself. Ray (1947) first mapped the metamorphic zones of Barrovian type on the basis of the first appearance of index minerals, viz., chlorite, biotite, garnet, staurolite, kyanite and sillimanite. He also identified that the rocks of the sillimanite-bearing gneisses occur at highest structural levels while chlorite-rich phyllite and schist occur at the bottom of the metamorphites. The Darjeeling formation comprises of migmatitic gneisses, Kyanite-staurolite-garnet-mica gneisses and sillimanite-garnet-mica ( \pm staurolite) gneisses.

The garnet-sillimanite bearing gneisses occupy higher elevations of the area and their occurrence is not persistent throughout. It is hard, compact and shows alternating bands of quartzo-feldspathic and micaceous material. It is composed of quartz, biotite, muscovite, garnet, feldspar and sillimanite. Needle-like sillimanite and pink blebs of garnet can be seen by naked eyes (figure 2). The sillimanite needles are maximum up to $1 \mathrm{~cm}$ in length. It is 60-m thick at Darjeeling town and extends further northwards for about $1.5 \mathrm{~km}$ along Kursyong road. It shows gradational contacts with migmatite. The garnet-sillimanite bearing gneiss dips $30^{\circ}-55^{\circ}$, NE. The sillimanite lineation plunges $12^{\circ}-16^{\circ}$, NNE. The gneiss is puckered, folded and boundinaged at Mangpu. Three generations of folds are recognized in Sikkim-Darjeeling Himalaya by Mukhopadhyay and Gangopadhyay (1971). First fold $\mathrm{F}_{1}$ is very tight, near isoclinals and is recognizable on minor scales. Trend of the lineation $\left(\mathrm{L}_{1}\right)$ is NE/ENE$\mathrm{SW} / \mathrm{WSW} . \mathrm{F}_{2}$ is moderately tight to open and the trend of $\mathrm{F}_{2}$ is NW-SE. The youngest fold $\mathrm{F}_{3}$ are open folds and the axis usually trend NE-SW. The second deformation $\left(\mathrm{D}_{2}\right)$ associated with the Himalayan orogeny is responsible for the generation of appressed, isoclinal, recumbent/reclined flattened flexure slip fold $\left(\mathrm{F}_{2}\right)$ on all scales with occasional axial planar crenulation cleavages and pervasive schistosity (figure 3a). These folds apparently represent a stage of superimposed fields of strain during progressive deformation. These folds indicate that the strain exhibited is the result of the operation of extension which has been superimposed on previous overall compression. The area under study also exhibits intense degree of mobilization marked by ptygmatic veining (figure $3 \mathrm{~b}$ ). Extreme cases of mobilization of gneisses result in the formation of locally granitized zones, leading to biotite granite gneisses.

\section{Textural relations and chronology of the phases of deformation and metamorphic crystallization}

The pelitic rocks of Darjeeling area are represented by the coarse-grained garnet-sillimanite bearing gneisses. The high-grade gneisses with fibrolite to phyllitic composition of rocks occurring from Darjeeling to Tista valley represent a classical Barrovian metamorphism. Five metamorphic zones have been established on the basis of development of typical index minerals, viz., chlorite, biotite, almandine, kyanite and sillimanite. The area around Darjeeling is unique in the sense that it

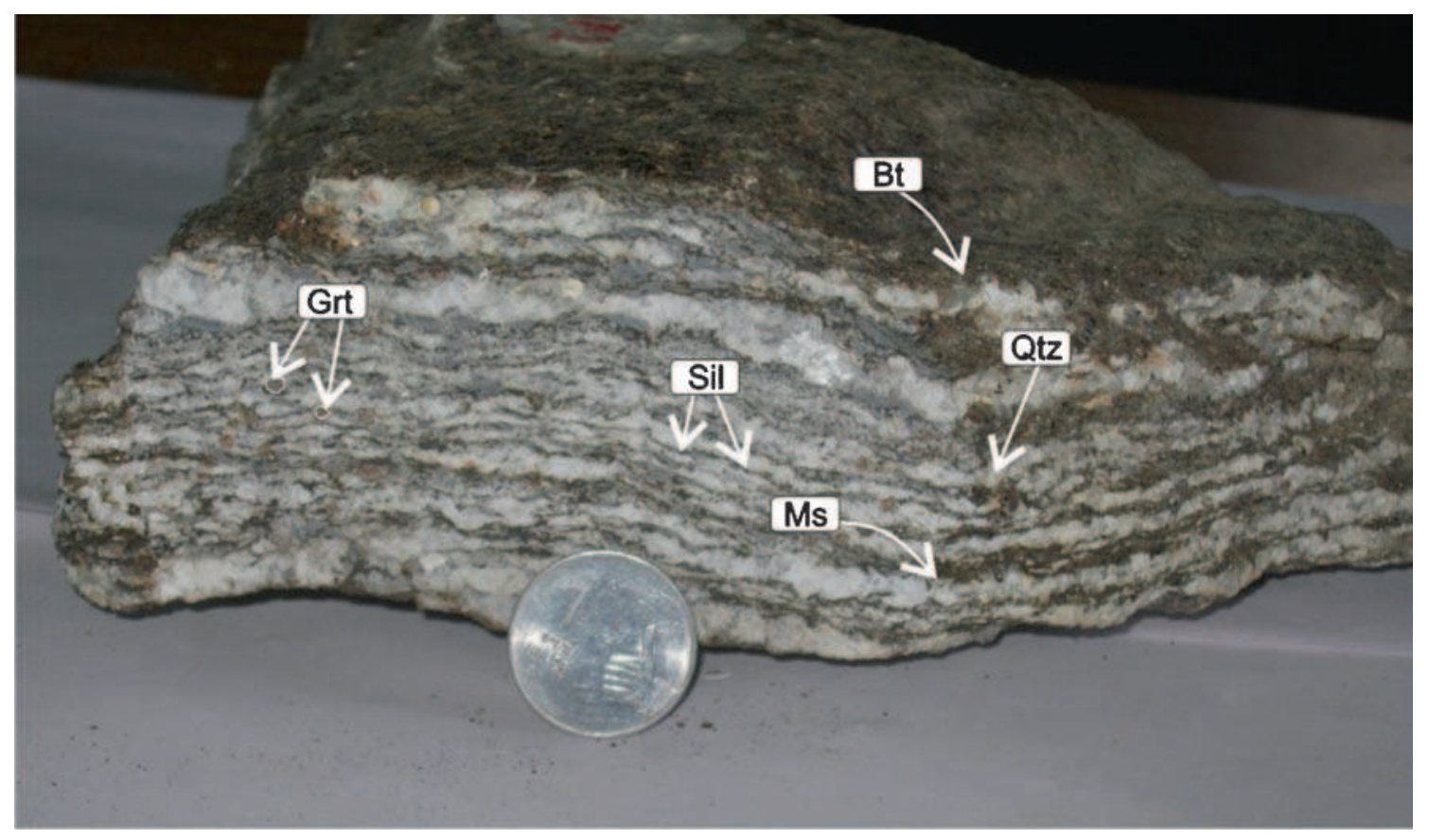

Figure 2. Close-up view of hand-specimen of Darjeeling gneiss showing garnet, sillimanite and biotite with other minerals. 

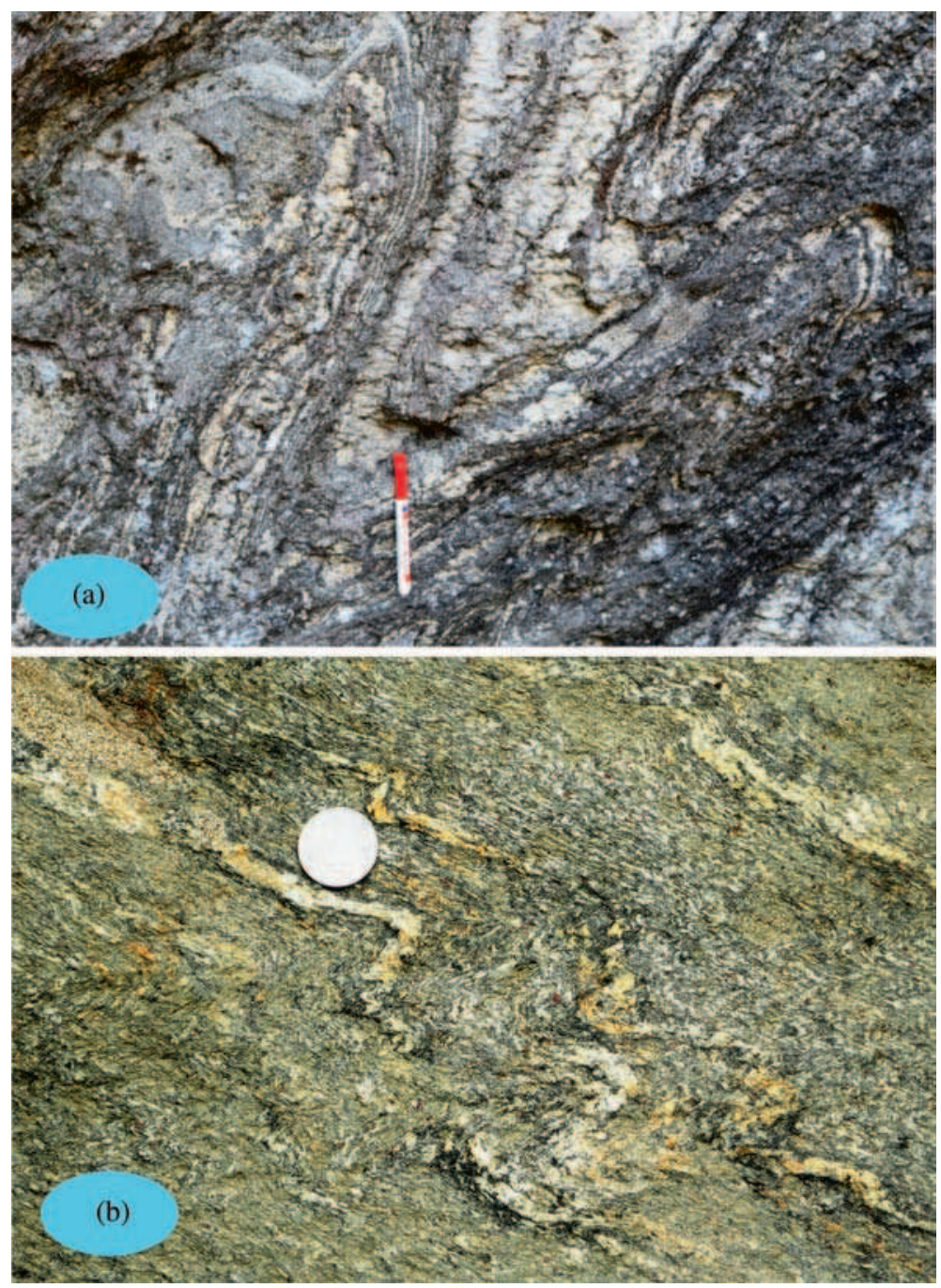

Figure 3. (a) Isoclinal folding in Darjeeling gneiss and (b) an irregular, lobate layer in Darjeeling gneiss showing ptygmatic folding.

is situated at higher structural levels and belongs to sillimanite zone. Prograde chlorite is absent in this zone. Garnet, commonly occurs as porphyroblasts are xenoblastic and sieve textured with inclusions of quartz, biotite, muscovite, ilmenite and rarely staurolite, plagioclase and kyanite (figure 4a). Various macro and micro structures are present in this area and the rocks of the area have suffered at least three phases of deformation. The original bedding plane $\left(\mathrm{S}_{0}\right)$ changes into the schistosity plane $\left(\mathrm{S}_{1}\right)$ due to the $\mathrm{D}_{1}$ deformation and $\mathrm{F}_{1}$ folding followed by the $\mathrm{D}_{2}$ deformation and $\mathrm{F}_{2}$ folding of the $S_{1}$ plane forming $S_{2}$ crenulation cleavage. Lastly, the $\mathrm{D}_{3}$ deformation developed by the refolding of $\mathrm{F}_{2}$ into $\mathrm{F}_{3}$ and formation of the $\mathrm{S}_{3}$ axial-plane crenulation cleavage. The textural features suggest syn-tectonic to post-tectonic crystallization of muscovite with respect to $\mathrm{D}_{1}$, followed by postcrystalline deformation during the subsequent folding movements. Sillimanite commonly occurs as fine-grained needle-like grains (fibrolite). Decrease in the modal content of kyanite, and the absence of K-feldspar association with kyanite indicate that sillimanite could have been derived by the polyphase transformation of kyanite (Mohan et al. 1989; Lal et al. 2005).

$$
\text { Kyanite }=\text { Sillimanite }
$$

The reaction (1) may also be a result of the breakdown of garnet and staurolite-bearing assemblages, instead of the breakdown of muscovite in the presence of quartz (Banerjee and Bhattacharya 1981; Mohan et al. 1989; Lal et al. 2005). Garnet prophyroblasts showing replacement by sillimanite, which is intergrown with biotite, indicate the resorption of garnet through the reaction (figure $4 \mathrm{~b}$ ):

Garnet + muscovite $=$ sillimanite + biotite + quartz

Mostly, the sillimanite as fibrolite mats is intergrown with micas (figure 4c). Kyanite is present as relict in the sample no. T4 (figure $4 \mathrm{~d}$ ). The 

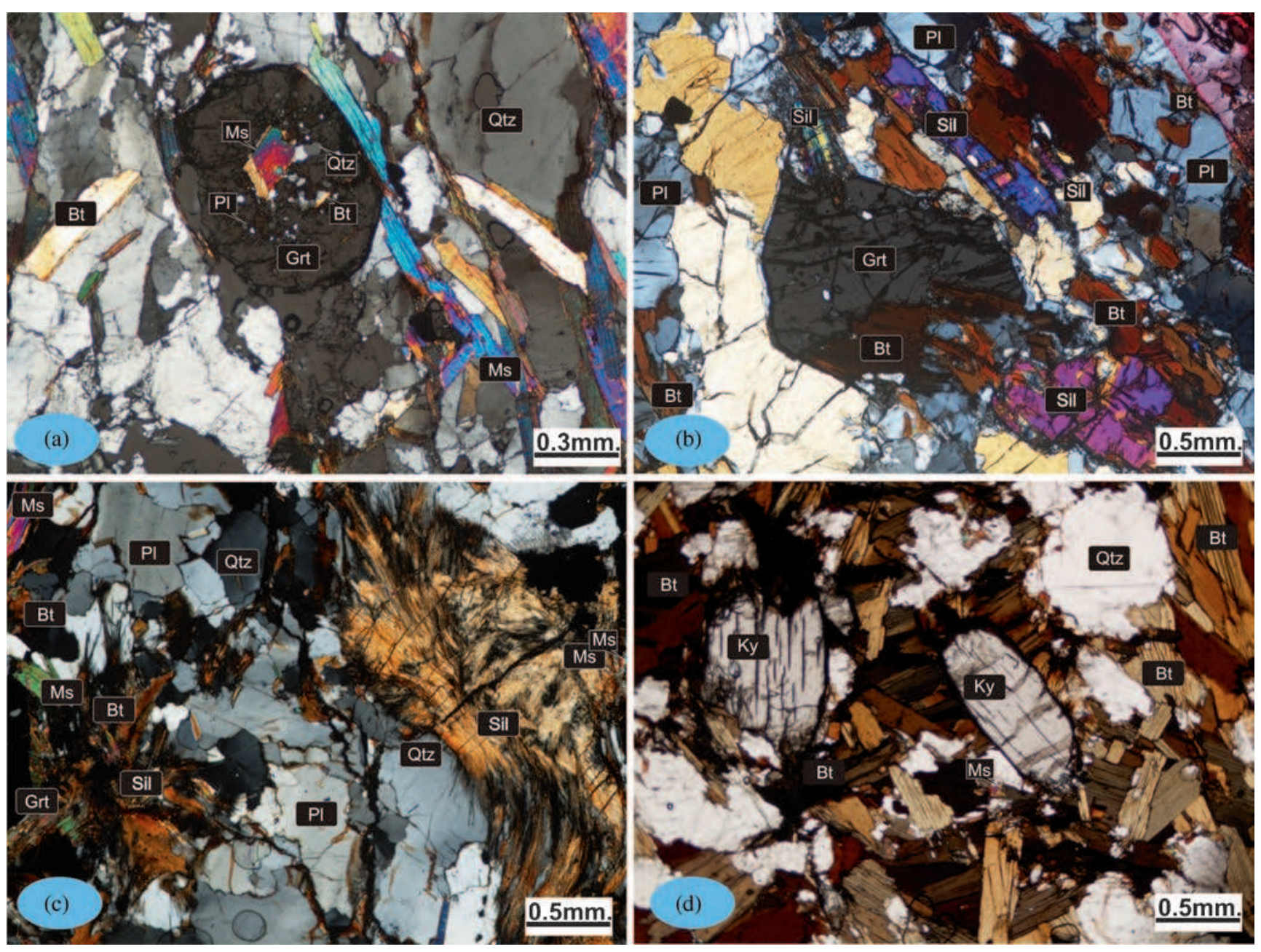

Figure 4. Photomicrographs illustrating textural relations in the Darjeeling gneiss. (a) Poikiloblastic garnet containing inclusions of quartz, biotite and muscovite (in XPL), (b) sillimanite occuring along with biotite at the rim of garnet porphyroblast (in XPL), (c) sillimanite 6(fibrolite) intergrown with muscovite (in XPL), and (d) relict kyanite enclosed within an aggregate of biotite (in PPL).

crystallization of garnet began prior to that of staurolite and kyanite; it continued to grow even after the formation of these minerals, and its crystallization ceased before the development of fibrolite (cf. Prakash and Tewari 2013).

\section{Mineral chemistry}

The mineral chemistry were carried out by SX100 CAMECA Electron Probe Micro Analyzer (EPMA) at Wadia Institute of Himalayan Geology, Dehradun, India under comparable operating conditions of $15 \mathrm{keV}$ accelerating voltage, $20 \mathrm{nA}$ beam current and beam size of $1 \mu \mathrm{m}$. The representative microprobe analyses of various minerals are listed in table 1. The stoichiometry of the garnets corresponds closely to the ideal formula: $\left(\mathrm{Fe}^{2+}, \mathrm{Mg}, \mathrm{Mn}\right.$, $\mathrm{Ca})_{3}\left(\mathrm{Al}, \mathrm{Ti}, \mathrm{Cr}, \mathrm{Fe}^{3+}\right)_{2} \mathrm{Si}_{3} \mathrm{O}_{12}$. Garnet is essentially almandine $(\sim 75 \mathrm{~mol} \%)$-pyrope $(\sim 15 \mathrm{~mol} \%)$ rich. Grossular and spessartine components are rather low.
The structural formulae of the biotites are similar to other biotites from metamorphic rocks (Deer et al. 1962, vol. 3) and deviate from the general formulae of ideal trioctahedral mica as the total number of cations at the Y-site falls short of the possible six per formula unit. This is apparently related to heterovalent substitution in octahedral layer as discussed by Foster (1960). The alkali deficiency, i.e., $\mathrm{X}<2.0$, present in the biotites is not abnormal for these metamorphic trioctahedral micas (cf. Guidotti 1974). Biotite has a homogenous composition and shows extensive $\mathrm{Fe}-\mathrm{Mg}$ solid solution. Biotite in immediate contact with garnet is Fe-rich compared with biotite in the matrix. Biotite with $\sim 4 \mathrm{wt} \% \mathrm{TiO}_{2}$ is characteristic of this mineral when associated with pelitic gneisses. The $\mathrm{X}_{\mathrm{Mg}}$ of biotite ranges between 0.36 and 0.38 .

The staurolite has slightly higher Al-content and lower octahedral sum compared with the ideal formula of $(\mathrm{Fe}, \mathrm{Mg})_{2} \mathrm{Al}_{5} \mathrm{Si}_{4} \mathrm{O}_{23}(\mathrm{OH})$ proposed by Thompson (1976). Similar feature has been 
Table 1. Representative microprobe analyses of the coexisting minerals (sample no. T4).

\begin{tabular}{|c|c|c|c|c|c|c|c|c|c|c|c|}
\hline & $\operatorname{Grt}(\mathrm{c})$ & $\operatorname{Grt}(\mathrm{r})$ & $\operatorname{Bt}(\mathrm{m})$ & $\mathrm{Bt}(\mathrm{m})$ & $\mathrm{St}(\mathrm{c})$ & $\mathrm{St}(\mathrm{r})$ & $\operatorname{Mus}(m)$ & $\operatorname{Mus}(\mathrm{m})$ & $\mathrm{Pl}(\mathrm{c})$ & $\mathrm{Pl}(\mathrm{r})$ & $\mathrm{Ilm}$ \\
\hline $\mathrm{SiO}_{2}$ & 37.18 & 36.07 & 34.66 & 34.04 & 27.94 & 27.75 & 46.27 & 47.51 & 61.57 & 60.72 & 0.02 \\
\hline $\mathrm{TiO}_{2}$ & 0.01 & 0.00 & 4.06 & 3.49 & 0.87 & 0.82 & 0.85 & 0.87 & 0.00 & 0.00 & 53.78 \\
\hline $\mathrm{Al}_{2} \mathrm{O}_{3}$ & 21.26 & 21.55 & 19.00 & 18.76 & 52.97 & 52.62 & 35.09 & 35.46 & 24.29 & 24.82 & 0.02 \\
\hline $\mathrm{Cr}_{2} \mathrm{O}_{3}$ & 0.04 & 0.05 & 0.00 & 0.00 & 0.00 & 0.000 & 0.00 & 0.00 & 0.00 & 0.00 & 0.04 \\
\hline $\mathrm{FeO}$ & 34.33 & 33.97 & 21.76 & 22.67 & 13.67 & 13.94 & 1.23 & 1.35 & 0.03 & 0.05 & 46.92 \\
\hline $\mathrm{MnO}$ & 2.65 & 3.88 & 0.13 & 0.21 & 0.11 & 0.18 & 0.00 & 0.00 & 0.00 & 0.00 & 1.03 \\
\hline $\mathrm{CaO}$ & 1.33 & 1.45 & 0.00 & 0.02 & 0.00 & 0.00 & 0.01 & 0.02 & 5.37 & 5.86 & 0.02 \\
\hline $\mathrm{MgO}$ & 3.79 & 3.06 & 7.29 & 6.98 & 1.69 & 1.59 & 1.15 & 1.19 & 0.00 & 0.00 & 0.20 \\
\hline $\mathrm{K}_{2} \mathrm{O}$ & 0.00 & 0.00 & 9.24 & 9.20 & 0.00 & 0.00 & 9.94 & 10.39 & 0.32 & 0.21 & 0.00 \\
\hline $\mathrm{Na}_{2} \mathrm{O}$ & 0.00 & 0.00 & 0.17 & 0.16 & 0.00 & 0.00 & 0.29 & 0.39 & 8.42 & 8.31 & 0.00 \\
\hline Total & 100.60 & 100.03 & 96.30 & 95.52 & 97.75 & 97.46 & 94.84 & 95.91 & 100.01 & 99.98 & 102.03 \\
\hline Oxygen basis & 12 & 12 & 22 & 22 & 23 & 23 & 22 & 22 & 8 & 8 & 4 \\
\hline $\mathrm{Si}$ & 2.974 & 2.923 & 5.290 & 5.270 & 3.889 & 3.884 & 6.160 & 6.128 & 2.733 & 2.701 & 0.001 \\
\hline $\mathrm{Al}^{\mathrm{IV}}$ & 0.026 & 0.077 & 2.710 & 2.730 & 0.111 & 0.116 & 1.840 & 1.872 & 1.271 & 1.301 & 0.000 \\
\hline $\mathrm{Al}^{\mathrm{VI}}$ & 1.978 & 1.981 & 0.700 & 0.690 & 8.578 & 8.562 & 3.666 & 3.634 & 0.000 & 0.000 & 0.000 \\
\hline $\mathrm{Ti}$ & 0.001 & 0.000 & 0.460 & 0.410 & 0.091 & 0.086 & 0.085 & 0.086 & 0.000 & 0.000 & 3.896 \\
\hline $\mathrm{Fe}^{3+}$ & 0.019 & 0.016 & 0.000 & 0.000 & 0.000 & 0.000 & 0.000 & 0.000 & 0.000 & 0.000 & 0.754 \\
\hline $\mathrm{Cr}$ & 0.003 & 0.003 & 0.000 & 0.000 & 0.000 & 0.000 & 0.000 & 0.000 & 0.000 & 0.000 & 0.001 \\
\hline $\mathrm{Fe}^{2+}$ & 2.277 & 2.286 & 2.770 & 2.930 & 1.591 & 1.631 & 0.137 & 0.149 & 0.001 & 0.002 & 3.462 \\
\hline Mn & 0.180 & 0.266 & 0.020 & 0.030 & 0.013 & 0.021 & 0.000 & 0.000 & 0.000 & 0.000 & 0.084 \\
\hline $\mathrm{Mg}$ & 0.451 & 0.369 & 1.660 & 1.610 & 0.351 & 0.332 & 0.228 & 0.234 & 0.000 & 0.000 & 0.029 \\
\hline $\mathrm{Ca}$ & 0.114 & 0.126 & 0.000 & 0.000 & 0.000 & 0.000 & 0.001 & 0.003 & 0.255 & 0.279 & 0.003 \\
\hline $\mathrm{K}$ & 0.000 & 0.000 & 1.800 & 1.820 & 0.000 & 0.000 & 1.688 & 1.746 & 0.018 & 0.012 & 0.000 \\
\hline $\mathrm{Na}$ & 0.000 & 0.000 & 0.050 & 0.050 & 0.000 & 0.000 & 0.075 & 0.100 & 0.725 & 0.717 & 0.000 \\
\hline $\mathrm{X}_{\mathrm{Mg}}$ or $\mathrm{X}_{\mathrm{Ca}}$ & 0.165 & 0.139 & 0.375 & 0.355 & 0.181 & 0.169 & 0.622 & 0.605 & 0.256 & 0.277 & - \\
\hline
\end{tabular}

$\mathrm{X}_{\mathrm{Mg}}=\mathrm{Mg} /\left(\mathrm{Fe}^{2+}+\mathrm{Mg}\right) ; \mathrm{X}_{\mathrm{Ca}}=\mathrm{Ca} /(\mathrm{Ca}+\mathrm{Na}+\mathrm{K}) ; \mathrm{m}=$ matrix; $\mathrm{c}=$ core; $\mathrm{r}=$ rim.

observed by microprobe analyses of staurolite from Sini area in Singhbhum district of Bihar (Lal and Ackermand 1979; Mohan et al. 1989). Staurolite is Fe-rich as $\mathrm{X}_{\mathrm{Mg}}$ ranges between 0.17 and 0.18.

Muscovite shows $\mathrm{X}_{\mathrm{Mg}}$ in the range of $0.60-0.62$ and it is a solid solution between muscovite and phengite. A celadonite-poor white mica crystallized in higher grades is related to the muscovitephengite by the Tschermak substitution, i.e., $\mathrm{Si}^{\mathrm{IV}}\left(\mathrm{Mg}, \mathrm{Fe}^{\mathrm{VI}}\right)=\mathrm{Al}^{\mathrm{IV}} \mathrm{Al}^{\mathrm{VI}} \cdot \mathrm{X}_{\mathrm{Cel}}$ component is low.

The formula of plagioclase shows persistent deficiency of $\sum \mathrm{Ca}+\mathrm{Mg}$ cations. A similar feature has been observed by Schreyer et al. (1975). They have proposed that the observed deficiency may be explained through deviations from ideal feldspar stoichiometry towards higher siliceous solid solution, for example, in pure albite by virtues of substitution $\mathrm{Si}=\mathrm{Na}, \mathrm{Al}$; and in anorthite through $\mathrm{Si}=$ $\mathrm{Al}, \mathrm{Ca}$ 0.5. Plagioclase is sodium rich and anorthite content is $\sim 25$ mole $\%$.

\section{Geothermobarometry and phase-equilibria modelling}

Metamorphic conditions of garnet-sillimanite bearing gneisses have been constrained through the application of (a) various geothermobarometric models of mineral equilibria, (b) internally consistent thermodynamic datasets of Berman (1988, 1990) and the updated TWEEQU computer programme, and (c) Perple_X 6.66 (Connolly 2005). The $\mathrm{P}-\mathrm{T}$ estimates for the core and the rim compositions obtained from the selected thermometers and barometers are given in table 2 . Temperature estimates were made using garnet-biotite, garnetmuscovite, garnet-staurolite and plagioclase-muscovite thermometers and pressure estimates with a garnet-plagioclase-biotite-muscovite-quartz and garnet-plagioclase-aluminosilicate-quartz barometer. The thermometric models of Goldman and Albee (1977), Dasgupta et al. (1991) and Bhattacharya et al. (1992) provide average temperatures of $684 \pm 17^{\circ}$ and $650 \pm 15^{\circ} \mathrm{C}$ for core and rim, respectively. However, the temperature values are raised by a minimum of $40^{\circ}-50^{\circ} \mathrm{C}$ using the models of Perchuk and Lavrent'eva (1983), Perchuk et al. (1985) and Indares and Martignole (1985). The $\mathrm{P}-\mathrm{T}$ conditions deduced from these geothermometers give an average temperature estimate of $706 \pm 31$ (core) and $678 \pm 40$ (rim) ${ }^{\circ} \mathrm{C}$. The garnetplagioclase-biotite-muscovite-quartz and garnetplagioclase-aluminosilicate-quartz assemblages permit the use of calibrations of Hoisch (1990), Newton 
Table 2. $P-T$ results using preferred models of geothermobarometery.

\begin{tabular}{|c|c|c|}
\hline \multirow[b]{2}{*}{ Models } & \multicolumn{2}{|c|}{ Temp. ${ }^{\circ} \mathrm{C}$ calculated at $6 \mathrm{kbar}$} \\
\hline & Core & Rim \\
\hline \multicolumn{3}{|l|}{ Geothermometry } \\
\hline \multicolumn{3}{|l|}{ Garnet-biotite thermometry } \\
\hline Goldman and Albee (1977) & 664 & 632 \\
\hline Perchuk and Lavrent'eva (1983) & 720 & 691 \\
\hline Perchuk et al. (1985) & 741 & 714 \\
\hline Indares and Martignole (1985) & 725 & 709 \\
\hline Dasgupta et al. (1991) & 693 & 658 \\
\hline Bhattacharya et al. (1992) & 695 & 659 \\
\hline \multicolumn{3}{|l|}{ Garnet-muscovite thermometry } \\
\hline Hoisch (1990) & 756 & 747 \\
\hline \multicolumn{3}{|l|}{ Garnet-staurolite thermometry } \\
\hline Perchuk (1990) & 672 & 631 \\
\hline \multicolumn{3}{|l|}{ Plagioclase-muscovite thermometry } \\
\hline Green and Usdansky (1986) & 621 & 606 \\
\hline \multirow[t]{2}{*}{ Average } & $706 \pm 31$ & $678 \pm 40$ \\
\hline & \multicolumn{2}{|c|}{ Pressure (kbar) calculated at $600^{\circ} \mathrm{C}$} \\
\hline Models & Core & Rim \\
\hline \multicolumn{3}{|c|}{ Geobarometry } \\
\hline \multicolumn{3}{|c|}{ Garnet-plagioclase-biotite-muscovite-quartz barometery } \\
\hline Hoisch $(1990)$ & 6.5 & 6.3 \\
\hline \multicolumn{3}{|c|}{ Garnet-plagioclase-aluminosilicate-quartz barometery } \\
\hline Newton and Haselton (1981)-Sill & 6.3 & 6.2 \\
\hline Newton and Haselton (1981)-Ky & 6.6 & 6.5 \\
\hline Hodges and Crowley (1985)-Sill & 6.3 & 6.2 \\
\hline Hodges and Crowley (1985)-Ky & 6.7 & 6.6 \\
\hline Koziol (1989)-Sill & 7.4 & 7.1 \\
\hline Koziol and Newton (1988)-Sill & 6.7 & 6.5 \\
\hline Average & $6.6 \pm .37$ & $6.4 \pm .31$ \\
\hline
\end{tabular}

and Haselton (1981), Koziol (1989), Koziol and Newton (1988) and Hodges and Crowley (1985) to estimate pressure conditions of chemical equilibration. Pressure conditions from different pertinent calibrations are estimated to be around $6.6 \pm 0.3$ (core) and $6.4 \pm 0.3$ (rim) kbar. Variations in pressure estimates are a consequence of the difference in the activity composition relations and the thermodynamic data utilized in these models.

$\mathrm{P}-\mathrm{T}$ estimates were also obtained using the internally consistent thermodynamic datasets of Berman (1988, 1990). The end-member phases used in the TWEEQU program calculations include almandine, pyrope, grossular, muscovite, annite, eastonite, phlogopite, anorthite, sillimanite, rutile, ilmenite and alpha-quartz. There are four possible equilibria that can be written for the selected endmember phases. Using these equilibria, core and rim compositions for sample $\mathrm{T} 4$ give precise intersection (figure 5 table 3 ) at $7.1 \mathrm{kbar}, 690^{\circ} \mathrm{C}$ (core) and $6.8 \mathrm{kbar}, 640^{\circ} \mathrm{C}(\mathrm{rim})$.

$\mathrm{P}-\mathrm{T}$ data have been obtained from equilibrium assemblage diagram (EAD, often referred as pseudosections), which were constructed with the software Perple_X 6.66 (Connolly 2005) (figure 6) and the internally consistent thermodynamic dataset in the KFMASH system. The detailed formula, notation and sources of the solution models are given in table 4. $\mathrm{P}-\mathrm{T}$ pseudosections for the pressure and temperature range (2-10 kbar and 200-800 ${ }^{\circ} \mathrm{C}$ ) was computed for garnet-sillimanite gneiss (sample no. T4) from the study area in the model system $\mathrm{KFMASH}\left(\mathrm{K}_{2} \mathrm{O}-\mathrm{FeO}-\mathrm{MgO}-\mathrm{Al}_{2} \mathrm{O}_{3}-\right.$ $\mathrm{SiO}_{2}-\mathrm{H}_{2} \mathrm{O}$ ) (figure 6). In the construction of the pseudosection for the sample no. T4, following phases and the corresponding phase components (in the parentheses) are chosen from those listed by the Perplex software, e.g., Grt (alm, prp and grs), Mica (phen, pa and ma), Chl (Mn chl), Bt (phl and east), $\mathrm{Pl}$ (ab and an) and St (fst and mst) and silicate melt phase (h2oL). Sillimanite and quartz are taken as pure phases. This diagram was contoured by $\mathrm{X}_{\mathrm{Mg}}, \mathrm{X}_{\mathrm{Ca}}$ and $\mathrm{X}_{\mathrm{Mn}}$ garnet isopleths, e.g., to the content of molar fractions of garnet components. The peak assemblage biotite-mica-garnet-sillimanite- 
albite is stable above $600^{\circ} \mathrm{C}$. The calculated isopleths for $\mathrm{X}_{\mathrm{Mg}}$ and $\mathrm{X}_{\mathrm{Ca}}$ garnet intersect at $7 \mathrm{kbar}$ and $690^{\circ} \mathrm{C}$ for the core composition whereas rim
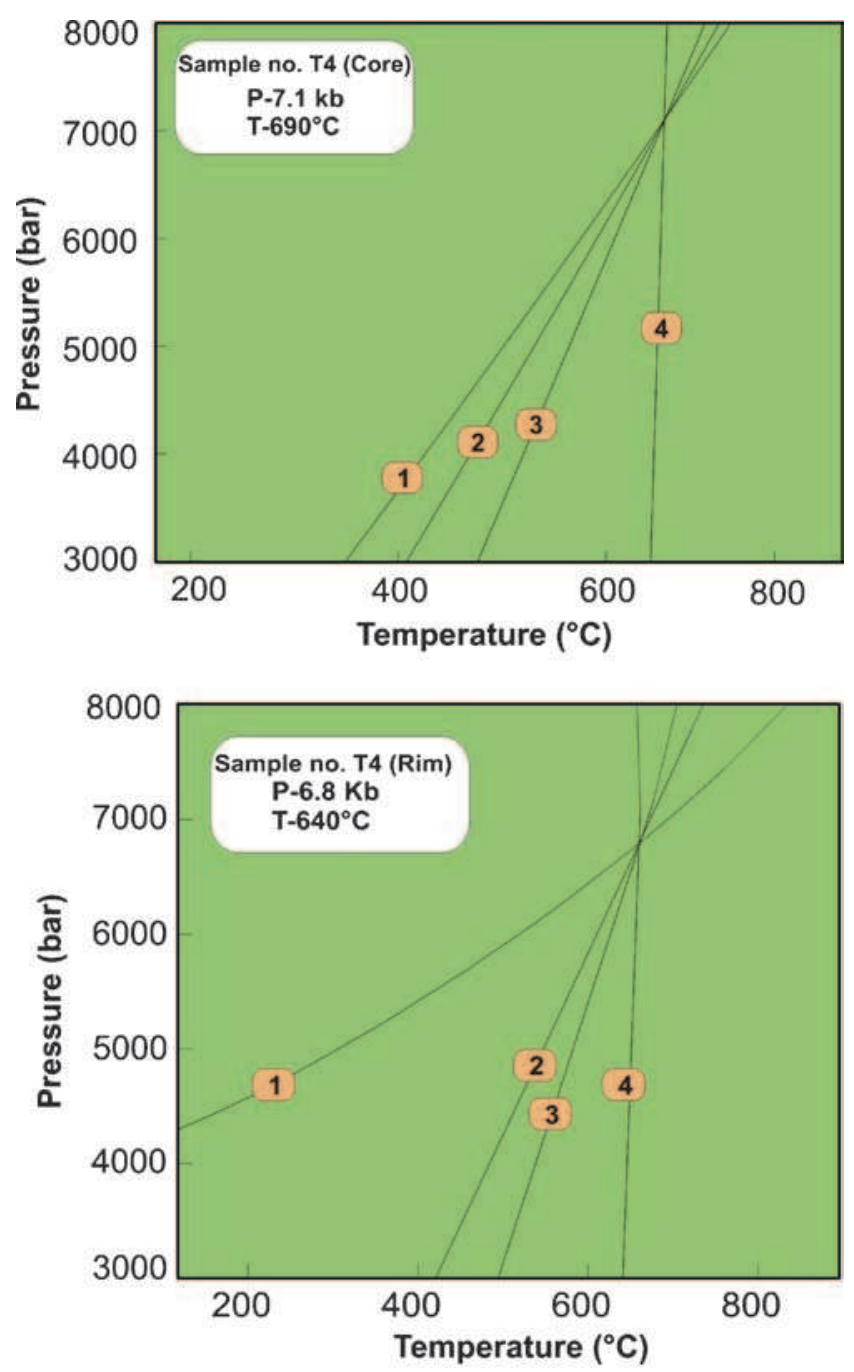

Figure 5. Simultaneous calculations of $\mathrm{P}-\mathrm{T}$ condition by TWEEQUE program for core and rim composition. compostion intersect at $6.5 \mathrm{kbar}$ and $680^{\circ} \mathrm{C}$. The calculated isopleths for garnet are well corroborated with the garnet composition obtained by EPMA. The $\mathrm{X}_{\mathrm{Mg}}$ and $\mathrm{X}_{\mathrm{Ca}}$ isopleths of garnet suggest peak $\mathrm{P}-\mathrm{T}$ condition of 7 kbar at $700^{\circ} \mathrm{C}$ for the formation biotite-mica-garnetsillimanite-albite-bearing assemblage of the study area.

\section{Discussion and conclusion}

Petrological studies on the Lesser- and Higher Himalayan crystallines have led to characterization of metamorphic reactions, including the melting reactions in the higher grades from fluidinduced melting to muscovite dehydration melting and biotite dehydration melting (Spear et al. 1999; White et al. 2003; Dasgupta et al. 2009). These studies have established that varying bulk compositions affected the distribution of metamorphic isograds. The productivity of the melt depends on which melting reactions are reached during the $\mathrm{P}$-T-time evolution, the availability of fluids and the bulk rock composition. The latter can be reasonably estimated from the observed composition. The dynamics of crustal melting in collisional settings has major implications. The collisional environment and melting of high grade gneisses have been envisaged for the origin of leucogranite formation in Himalayas (LeFort et al. 1987; Crawford and Windley 1990). In this model, the melting has been induced in sillimanite gneisses of Tibetan crystalline slab by 'hot over cold' thrusting and subsequent fluxing of fluids derived from dehydration of metasediments overthrust by the gneisses. Subsequent fluid flux caused 'wet melting' in the gneisses to generate minimum melt which moved a short distance from the source and

Table 3. Simultaneous calculation of P-T by TWEEQUE program (version Win 2.32).

\begin{tabular}{|c|c|c|c|}
\hline & $\mathrm{dH}$ & $\mathrm{dS}\left(\mathrm{JK}^{-1}\right)$ & $\mathrm{dV}\left(\mathrm{Jbar}^{-1}\right)$ \\
\hline \multicolumn{4}{|l|}{ Equilibria plotted in figure 5} \\
\hline \multicolumn{4}{|l|}{ Sample no. T4 (core) } \\
\hline 1. $\mathrm{Gr}+\alpha \mathrm{Qtz}+2 \mathrm{Sil}=3 \mathrm{An}$ & -12.3 & -4.67 & -0.23 \\
\hline 2. $\mathrm{Ms}+\mathrm{Gr}+\mathrm{Alm}=\mathrm{Ann}+3 \mathrm{An}$ & -12.2 & -3.55 & -0.21 \\
\hline 3. $4 \alpha \mathrm{Qtz}+3 \mathrm{Eas}+3 \mathrm{Alm}=3 \mathrm{Ann}+2 \mathrm{Py}+4 \mathrm{Sil}$ & -13.4 & -0.79 & -0.01 \\
\hline 4. $2 \mathrm{Ms}+\mathrm{Phl}+\mathrm{Py}=6 \alpha \mathrm{Qtz}+3 \mathrm{Eas}$ & -0.5 & -0.24 & 0.07 \\
\hline 5. $3 \mathrm{Ms}+2 \mathrm{Py}=2 \mathrm{Sil}+7 \alpha \mathrm{Qtz}+3 \mathrm{Eas}$ & -10.6 & -0.26 & 0.09 \\
\hline \multicolumn{4}{|l|}{ Sample no. T4 (rim) } \\
\hline 1. $3 \mathrm{Rt}+\mathrm{Alm}=3 \mathrm{Ilm}+2 \alpha \mathrm{Qtz}+$ Sil & 3.4 & -0.65 & -0.1 \\
\hline 2. $6 \alpha \mathrm{Qtz}+\mathrm{Py}+2 \mathrm{Gr}+3 \mathrm{Eas}=6 \mathrm{An}+3 \mathrm{Phl}$ & -0.3 & -2.71 & -0.13 \\
\hline 3. $2 \mathrm{Sil}+\alpha \mathrm{Qtz}+\mathrm{Gr}=3 \mathrm{An}$ & -12.3 & -4.67 & -0.23 \\
\hline 4. $\mathrm{Ms}+\mathrm{Gr}+\mathrm{Alm}=\mathrm{Ann}+3 \mathrm{An}$ & -12.2 & -3.55 & -0.21 \\
\hline 5. Phl+Alm $=\mathrm{Py}+\mathrm{Ann}$ & -22.7 & -0.83 & -0.01 \\
\hline
\end{tabular}

$\mathrm{dS}$ and $\mathrm{dV}$ are calculated at $1 \mathrm{kbar}$ and $298 \mathrm{~K}$. 

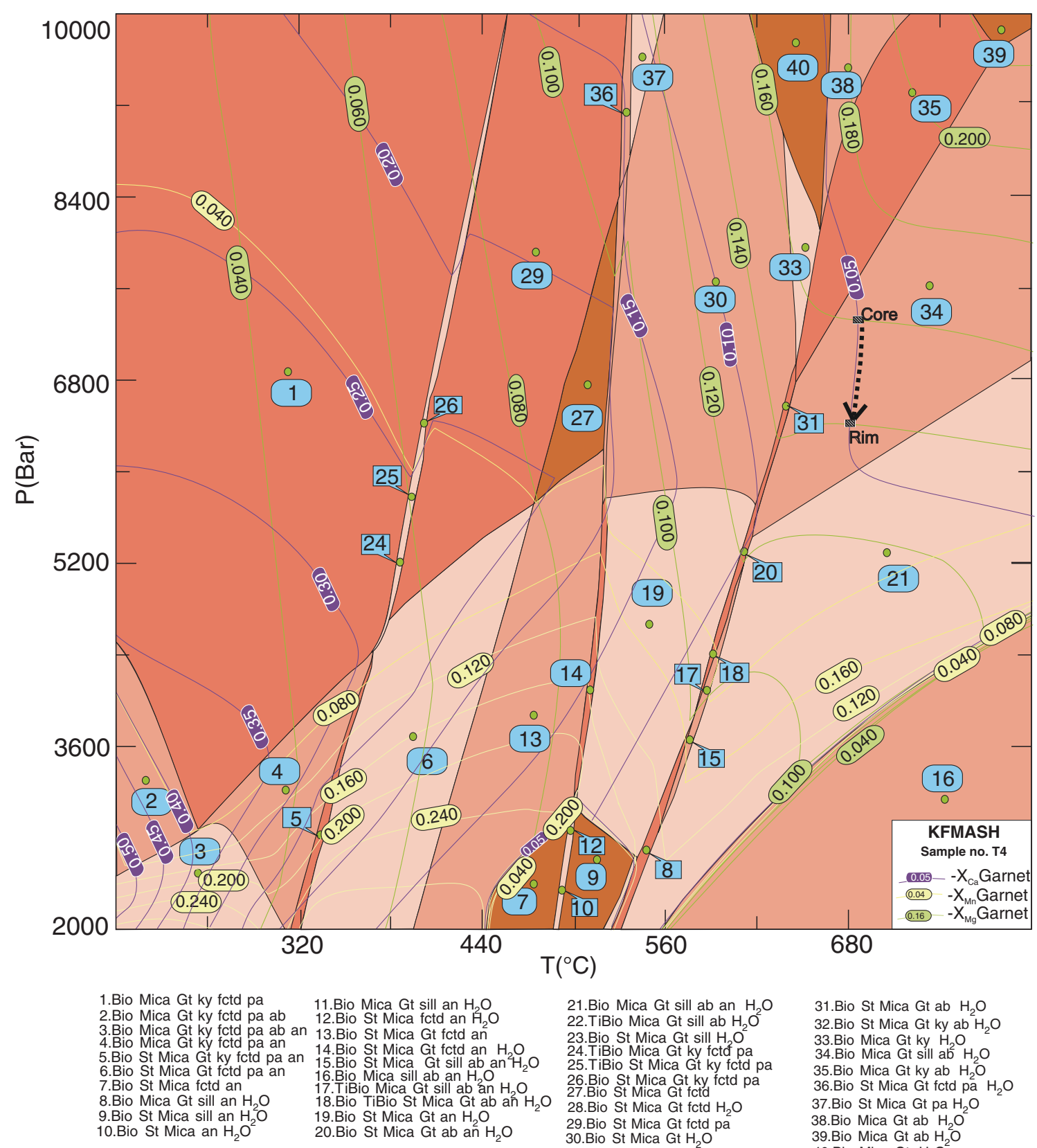

21. Bio Mica Gt sill ab an $\mathrm{H}_{2} \mathrm{O}$ 22. TiBio Mica Gt sill ab $\mathrm{H}_{2} \mathrm{O}$ 23. Bio St Mica Gt sill $\mathrm{H}_{2} \mathrm{O}$ 24. TiBio Mica Gt ky fcto pa 26. Bio St Mica Gt ky fctd pa 26. Bio St Mica Gt ky 28. Bio St Mica Gt fctd $\mathrm{H}_{2} \mathrm{O}$ 29. Bio St Mica Gt fctd pa 30. Bio St Mica Gt $\mathrm{H}_{2} \mathrm{O}$
31.Bio St Mica Gt ab $\mathrm{H}_{2} \mathrm{O}$ 32. Bio St Mica Gt ky ab $\mathrm{H}_{2} \mathrm{O}$ 33. Bio Mica Gt ky $\mathrm{H}_{2} \mathrm{O}$ 34.Bio Mica Gt sill ab $\mathrm{H}_{2} \mathrm{O}$ 35. Bio Mica Gt ky ab $\mathrm{H}_{2} \mathrm{O}$ 36. Bio St Mica Gt fetd pa $\mathrm{H}_{2} \mathrm{O}$ 37. Bio St Mica Gt pa $\mathrm{H}_{2} \mathrm{O}$ 38. Bio Mica Gt ab $\mathrm{H}_{2} \mathrm{O}$ 39. Bio Mica $\mathrm{Gt}$ ab $\mathrm{H}_{2} \mathrm{O}$ 40.Bio Mica Gt $\mathrm{H}_{2} \mathrm{O}_{2}$

Figure 6. Calculated P-T pseudosection for Darjeeling gneiss (sample no. T4) in the KFMASH system. Bulk composition in wt\% $\left(\mathrm{Na}_{2} \mathrm{O}\right.$ 1.19, $\mathrm{MgO} 3.34, \mathrm{Al}_{2} \mathrm{O}_{3}$ 19.07, $\mathrm{SiO}_{2}$ 62.66, $\mathrm{P}_{2} \mathrm{O}_{5}$ 0.11, $\mathrm{K}_{2} \mathrm{O}$ 4.25, $\mathrm{CaO} 0.24, \mathrm{TiO}_{2}$ 0.55, $\left.\mathrm{Mn}_{0.04}, \mathrm{Fe}_{2} \mathrm{O}_{3} 6.24\right)$. The pseudosection has been contoured for the isopleth $\mathrm{X}_{\mathrm{Mg}}, \mathrm{X}_{\mathrm{Ca}}$ and $\mathrm{X}_{\mathrm{Mn}}$ garnet. Calculation of $\mathrm{P}-\mathrm{T}$ condition using core and rim composition of garnet by the intersection of $\mathrm{X}_{\mathrm{Mg}}$ (garnet) and $\mathrm{X}_{\mathrm{Ca}}$ (garnet).

generated leucogranites. In the high Himalaya, the central crystallines or the Tibetan slab gneisses are thrust over Lesser Himalaya along the MCT. The above model has been reviewed in detail by Dasgupta et al. (2009), Basu (2013) and Rubatto et al. (2013).

A comparison of the estimated temperature range of $700^{\circ} \mathrm{C}$ for the sillimanite zone with the minimum anatexis curve valid for plagioclase $\mathrm{An}_{26}$ (Winkler 1978) suggests that widespread melting in the gneiss should occur in this zone through the melting reaction

$$
\begin{aligned}
& \text { Muscovite }+ \text { albite }+ \text { quartz }+\mathrm{H}_{2} \mathrm{O} \\
& \quad=\text { melt }+ \text { sillimanite }
\end{aligned}
$$

The melting reaction lies at higher temperatures $\left(\sim 650^{\circ} \mathrm{C} / 7 \mathrm{kbar}\right)$ than the minimum anatexis of granite through the reaction (Winkler 1978)

Albite + orthoclase + quartz $+\mathrm{H}_{2} \mathrm{O}=$ melt (4) 
Table 4. Solution notation, formula and model sources for phase diagram calculation.

\begin{tabular}{|c|c|c|c|c|}
\hline $\begin{array}{l}\text { Symbols in } \\
\text { Perple_X } \\
\text { solution model file }\end{array}$ & $\begin{array}{l}\text { Symbols used } \\
\text { indrawn } \\
\text { pseudosections }\end{array}$ & $\begin{array}{l}\text { Solutions } \\
\text { name }\end{array}$ & Formula & Source \\
\hline $\mathrm{Bio}(\mathrm{HP})$ & $\mathrm{Bt}$ & Biotite & $\begin{array}{c}\mathrm{K}\left[\mathrm{Mg}_{x} \mathrm{Fe}_{y} \mathrm{Mn}_{1-x-y}\right]_{3-w} \\
\mathrm{Al}_{1+2 w} \mathrm{Si}_{3-w} \mathrm{O}_{10}(\mathrm{OH})_{2}, x+y \leq 1\end{array}$ & Powell and Holland (1999) \\
\hline TiBio(HP) & $\mathrm{Bt}$ & Biotite & $\begin{array}{c}\mathrm{K}\left[\mathrm{Mg}_{x} \mathrm{Fe}_{y} \mathrm{Mn}_{1-x-y}\right]_{3-w-z / 2} \\
\mathrm{Ti}_{z} \mathrm{Al}_{1+2 w} \mathrm{Si}_{3-w} \mathrm{O}_{10}(\mathrm{OH})_{2}, x+y \leq 1\end{array}$ & $\begin{array}{l}\text { Powell and Holland (1999); } \\
\text { White et al. (2000) }\end{array}$ \\
\hline $\mathrm{Gt}(\mathrm{HP})$ & Grt & Garnet & $\begin{array}{l}\mathrm{Fe}_{3 x} \mathrm{Ca}_{3 y} \mathrm{Mg}_{3 z} \mathrm{Mn}_{3(1-x-y-z)} \\
\mathrm{Al}_{2} \mathrm{Si}_{3} \mathrm{O}_{12}, x+y+z \leq 1\end{array}$ & Holland and Powell (1998) \\
\hline $\mathrm{Chl}(\mathrm{HP})$ & $\mathrm{Chl}$ & Chlorite & $\begin{array}{c}{\left[\mathrm{Mg}_{x} \mathrm{Fe}_{w} \mathrm{Mn}_{1-x-w}\right]_{5-y+z}} \\
\mathrm{Al}_{2(1+y-z)} \mathrm{Si}_{3-y+z} \mathrm{O}_{10}(\mathrm{OH})_{8}, x+w \leq 1\end{array}$ & Holland et al. (1998) \\
\hline $\operatorname{Mica}(\mathrm{CHA})$ & Mica & Muscovite & $\begin{array}{c}\mathrm{K}_{y} \mathrm{Ca}_{x} \mathrm{Na}_{1-x-y}\left(\mathrm{Mg}_{1-v} \mathrm{Fe}_{v}\right)_{z} \\
\mathrm{Mg}_{w} \mathrm{Ti}_{w} \mathrm{Al}_{3+x-w-z} \mathrm{Si}_{3-x+z} \mathrm{O}_{10}(\mathrm{OH})_{2} \\
x+y<1, w+z<y\end{array}$ & $\begin{array}{l}\text { Coggon and Holland (2002); } \\
\text { Auzanneau et al. (2010) }\end{array}$ \\
\hline Pheng(HP) & Mica & Muscovite & $\begin{array}{c}\mathrm{K}_{x} \mathrm{Na}_{1-x} \mathrm{Mg}_{y} \mathrm{Fe}_{z} \mathrm{Al}_{3-2(y+z)} \\
\mathrm{Si}_{3+y+z} \mathrm{O}_{10}(\mathrm{OH})_{2}\end{array}$ & Holland and Powell (1998) \\
\hline $\mathrm{St}(\mathrm{HP})$ & St & Staurolite & $\begin{array}{c}\mathrm{Mg}_{4 x} \mathrm{Fe}_{4 y} \mathrm{Mn}_{4(1-x-y)} \\
\mathrm{Al}_{18} \mathrm{Si}_{7.5} \mathrm{O}_{48} \mathrm{H}_{4}, x+y \leq 1\end{array}$ & Holland and Powell (1998) \\
\hline $\mathrm{Ctd}(\mathrm{HP})$ & Ctd & Chloritoid & $\begin{array}{c}\mathrm{Mg}_{x} \mathrm{Fe}_{y} \mathrm{Mn}_{1-x-y} \\
\mathrm{Al}_{2} \mathrm{SiO}_{5}(\mathrm{OH})_{2}, x+y \leq 1\end{array}$ & White et al. (2000) \\
\hline Melt(HP) & Melt & Melt & $\begin{array}{l}\text { Na-Mg-Al-Si-K-Ca-Fe } \\
\text { hydrous silicate melt }\end{array}$ & Holland and Powell (2001) \\
\hline $\mathrm{Pl}(\mathrm{I} 1, \mathrm{HP})$ & $\mathrm{Ab}, \mathrm{An}$ & $\begin{array}{l}\text { Plagioclase } \\
\text { Feldspar }\end{array}$ & $\begin{array}{l}\mathrm{K}_{y} \mathrm{Na}_{x} \mathrm{Ca}_{1-x-y} \mathrm{Al}_{2-x-y} \\
\mathrm{Si}_{2+x+y} \mathrm{O}_{8}, x+y \leq 1\end{array}$ & Holland and Powell (2003) \\
\hline
\end{tabular}

Although in less aluminous pelitic gneisses, Kfeldspar+muscovite do occur in this zone, sillimanite and K-feldspar are not found together in the aluminous gneisses. The absence of co-existing sillimanite $+\mathrm{K}$-feldspar and the stable occurrence of muscovite in the estimated $\mathrm{P}-\mathrm{T}$ conditions of this zone could be estimated as follows:

- Plagioclase in the gneisses is oligoclase and thus the melting reaction would shift to higher temperatures. Tracy (1978) calculated temperatures around $700^{\circ} \mathrm{C}$ for the reaction (4) in which plagioclase is anorthite instead of albite.

- It is also likely that the gneisses may not be saturated with water and thus the condition may have been between those of reaction (3) and the reaction $(5)$

$$
\begin{aligned}
& \text { Muscovite + albite + quartz } \\
& \quad=\mathrm{K} \text {-feldspar }+ \text { sillimanite }+\mathrm{H}_{2} \mathrm{O}
\end{aligned}
$$

The latter reaction occurs at $750^{\circ} \mathrm{C} / 7 \mathrm{kbar}$ (Thompson 1974) and would shift to still higher temperatures with the incorporation of anorthite molecule in plagioclase (cf. Tracy 1978).

Several other reactions have been proposed for the formation of sillimanite other than the above reactions. These may be summarized as follows:

Muscovite + quartz $=$ sillimanite $+\mathrm{K}$-feldspar $+\mathrm{H}_{2} \mathrm{O}$

Reaction (6) has been given by Turner and Verhoogen (1960) and Winkler (1978).

$$
\begin{aligned}
& \text { Staurolite }+ \text { muscovite }+ \text { quartz } \\
& \quad=\text { sillimanite }+ \text { biotite }+ \text { granet }+\mathrm{H}_{2} \mathrm{O}
\end{aligned}
$$

Above reaction (7) has been given by number of researchers, viz., Chakraborty and Sen (1967); Thompson and Norton (1968); Hollister (1969); Carmichael (1970); Froese and Gasparrini (1975); Lal and Singh (1978); Spear et al. (1999).

$$
\begin{aligned}
& \text { Staurolite }+ \text { muscovite }+ \text { chlorite }(\text { Na-rich }) \\
& =\text { sillimanite }+ \text { biotite }+ \text { muscovite }+ \text { albite } \\
& \quad+\text { quartz }+\mathrm{H}_{2} \mathrm{O}(\text { K-rich })
\end{aligned}
$$

Above reaction has been given by Guidotti (1974).

The reactions (6) and (8) are not applicable in the area because of the instability of chlorite in the presence of muscovite + quartz and absence of K-feldspar in the sillimanite bearing gneisses 
respectively. Textural relations (see above) are also not in favour of the reaction (7).

According to Carmichael (1970), although sillimanite is rarely texturally associated with kyanite, the inversion of kyanite to sillimanite takes place by a series of reactions involving other phases which act as catalyst that is consumed at one step of the sequence of reaction at a later step. All the intermediate products cancel out of the reaction that expresses the net change taking place in the system, i.e., kyanite $=$ sillimanite $($ reaction 1$)$. Thus even though sillimanite is remote from kyanite in these rocks, the simple net reaction (1) may have been in progress. The common association of sillimanite with biotite according to Chinner (1961) appears to be nucleation phenomenon. The trigonally arranged chains of oxygen tetrahedra and octahedra in the alternate mica sheets acting as nuclei for the growth of the tetrahedral and octahedral chains constitutes the sillimanite structure. Nucleation is probably dominantly epitaxial, and alumina and silica for sillimanite growth are mainly derived from unstable kyanite and transferred to the sillimanite nuclei through the medium of fluid phase.

It is generally believed that melting is associated with process of anatexis in regions of high heat flow (Turner 1968; Winkler 1978). It is apparent from the disposition of the tectonic units (see figure 1) and the metamorphic zones that the central crystalline belts may have served as the locus of metamorphism producing widespread melting and higher grade metamorphic rocks in the regions of high heat flow and successive lower grade rocks away from it. Later thrusting during $\mathrm{D}_{2}$ deformation transported these rocks from regions near to central crystalline to lower Himalayas, thus producing inverted sequence of metamorphic zones. Therefore, in order to explain the pattern of regional metamorphism, it may be necessary to assume an abnormally high rate of heat flow in the region of Main Central Thrust from the underlying basement extending to the mantle to provide heat for the metamorphism. Due to random heat flow in some of the regions in lesser Himalaya, the muscovite dehydration melting reaction was not encountered and rock did not witness sillimanite-K-feldspar isograd.

Considering these effects of anorthite-content of plagioclase and the activity of water, and possible error in models of geothermometry and isochemical phase-diagram applied for estimated temperatures which certainly do not give results better than $\pm 50^{\circ} \mathrm{C}$ (cf. Tracy et al. 1976; Thompson 1976), the observed absence of K-feldspar in the sillimanitebearing gneisses does not appear to be anamolus. Therefore, the above study has an important bearing on the inverted metamorphic sequence in the Sikkim-Darjeeling Himalaya.

\section{Acknowledgements}

Authors thank the Head, Department of Geology, Banaras Hindu University and the CAS programme of the UGC at BHU for providing necessary infrastructural facilities. They also thank anonymous reviewers for the constructive comments that led to substantial improvement in the manuscript and deeply appreciate the editorial efficiency of Prof. M Jayananda.

\section{References}

Acharya S K 1978 Stratigraphy and tectonic features of eastern Himalaya; In: Tectonic Geology of the Himalaya (ed.) Saklani P S (Delhi: Today and Tomorrow's Publishers), pp. 243-269.

Auden J B 1935 Traverses in Himalaya; Rec. Geol. Surv. India 69(2) 161-167.

Auzanneau E, Schmidt M W, Vielzeuf D and Connolly J A D 2010 Titanium in phengite: A geobarometer for high temperature eclogites; Contrib. Mineral. Petrol. 159 1-24.

Banerjee H and Bhattacharya P K 1981 Concurrent granitization under different metamorphic facies conditions in the lesser Himalayas of the Sikkim-Darjeeling region; Neues Jahrbuch fur Mineral. Abhandlungen 142 199-222.

Basu S K 2013 Geology of Sikkim State and Darjeeling District of West Bengal; Geol. Soc. India 356.

Berman R G 1988 Internally consistent thermodynamic data for stoichiometric minerals in the system $\mathrm{Na}_{2} \mathrm{O}-$ $\mathrm{K}_{2} \mathrm{O}-\mathrm{CaO}-\mathrm{Al}_{2} \mathrm{O}_{3}-\mathrm{SiO}_{2}-\mathrm{TiO}_{2}-\mathrm{H}_{2} \mathrm{O}-\mathrm{CO}_{2} ;$ J. Petrol. 29 $45-522$.

Berman R G 1990 Mixing properties of $\mathrm{Ca}-\mathrm{Mg}-\mathrm{Fe}-\mathrm{Mn}$ garnets; Am. Mineral. 75 328-344.

Bhattacharya A, Mohanty L, Maji A, Sen S K and Raith M 1992 Non-ideal mixing in the phlogophite-annite binary: Constraints from experimental data on $\mathrm{Mg}-\mathrm{Fe}$ partitioning and a reformulation of the biotite-garnet geothermometers; Contrib. Mineral. Petrol. 111 87-93.

Bose P N 1891 Notes of the geological and mineral resources of Sikkim; Rec. Geol. Surv. India 26(24) 217-230.

Carmichael D M 1970 Intersecting isograds in the Whetstone lake area, Ontario; J. Petrol. 11 147-181.

Chakraborty K R and Sen S K 1967 Regional metamorphism of pelitic rocks around Kandra Singhbhum Bihar; Contrib. Mineral. Petrol. 16 210-232.

Chinner G A 1961 The origin of sillimanite in Glen Clova, Angus; J. Petrol. 2 312-323.

Coggon R and Holland T J B 2002 Mixing properties of phengitic micas and revised garnet-phengite thermobarometers; J. Metamor. Geol. 20 683-696.

Connolly J A D 2005 Computation of phase equilibria by linear programming: A toll for geodynamic modeling and its application to subduction zone decarbonation; Earth Planet. Sci. Lett. 236 524-541.

Crawford M B and Windley B F 1990 Leucogranites of Himalaya/Karakoram: Implications for migmatitic evolution within collisional belts and study of collision related leucogranite petrogenesis; J. Volcano. Geotherm. Res. 44 $1-19$.

Dasgupta S, Sengupata P, Guha D and Fukuoka D 1991 A refined garnet-biotite $\mathrm{Fe}-\mathrm{Mg}$ exchange geothermometer and its application in amphibolites and granulites; Contrib. Mineral. Petrol. 109 130-137.

Dasgupta S, Chakraborty S and Neogi S 2009 Petrology of an inverted Barrovian sequence of metapelites in Sikkim 
Himalaya, India: Constraints on the tectonic inversion; Am. J. Sci. 309 43-84.

Deer W A, Howie P A and Zussman J 1962 Rock-forming minerals; Longmann, London $\mathbf{1}$ and $\mathbf{3}$.

Foster M D 1960 Interpretation of the composition of trioctahedral micas; US Geol. Surv. Prof. Paper 354-B 24-49.

Froese E and Gasparrini E 1975 Metamorphic zones in the Snow Lake area, Manitoba; Can. Miner. 13 162-167.

Gansser A 1964 Geology of the Himalayas; Innterscience Publ., Wiley, New York, 289p.

Goldman D S and Albee A L 1977 Correlation of Mg/Fe partitioning between garnet and biotite with partitioning between quartz and magnetite; Am. J. Sci. 277 750-767.

Green N L and Usdansky S I 1986 Ternary-feldspar mixing relations and thermobarometry; Am. Mineral. 71 11001108.

Guidotti C V 1974 Transition from staurolite to sillimanite zone, Rangeley Quadrangle, Maine; Bull. Geol. Soc. Am. $85475-490$.

Gupta S, Das A, Goswami S, Modak A and Mondal S 2010 Evidence for structural discordance in the inverted metamorphic sequence of Sikkim Himalaya: Towards resolving the Main Central Thrust controversy; J. Geol. Soc. India 75 313-322.

Heim A and Gansser A 1939 Central Himalaya, geological observations of the Swiss expedition; Memoir Soc. Helv. Sci. Nat. 73(1) 1-245.

Hodges K V and Crowley P D 1985 Error estimation and empirical geothermobarometry for pelitic systems; $A m$. Mineral. 70 702-709.

Hoisch T D 1990 Empirical calibration of six geobarometers for the mineral assemblage quartz + muscovite + biotite + plagioclase + garnet; Contrib. Mineral. Petrol. $104225-234$.

Holland T J B and Powell R 1998 An internally consistent thermodynamic data set for phases of petrological interest; J. Metamor. Geol. 16 309-343.

Holland T and Powell R 2001 Calculation of phase relations involving haplogranitic melts using an internally consistent thermodynamic dataset; J. Petrol. 42 673-683.

Holland T and Powell R 2003 Activity-composition relations for phases in petrological calculations: An asymmetric multicomponent formulation; Contrib. Mineral. Petrol. 145 492-501.

Holland T, Baker J and Powell R 1998 Mixing properties and activity-composition relationships of chlorites in the system $\mathrm{MgO}-\mathrm{FeO}-\mathrm{Al}_{2} \mathrm{O}_{3}-\mathrm{SiO}_{2}-\mathrm{H}_{2} \mathrm{O}$; Euro. J. Mineral. $10395-406$.

Hollister L S 1969 Contact metamorphism in Kwoiek area, British Columbia: An end member of the metamorphic process; Geol. Soc. Am. Bull. 80 2465-2494.

Indares A and Martignole J 1985 Biotite-garnet thermometry in the granulite facies: The influence of $\mathrm{Ti}$ and $\mathrm{Al}$ in biotite; Am. Mineral. 70 272-278.

Jangpangi B S 1972 Some observations on the stratigraphy and reverse metamorphism in Darjeeling Hills; Him. Geol. 2 356-370.

Koziol A M 1989 Recalibration of garnet-plagioclase- $\mathrm{Al}_{2} \mathrm{SiO}_{5}-$ quartz (GASP) geobarometer and applications to natural parageneses; EOS (Trans. Am. Geophys. Union) 70493.

Koziol A M and Newton R C 1988 Redetermination of the anorthite breakdown and improvement of the plagioclasegarnet- $\mathrm{Al}_{2} \mathrm{SiO}_{5}$-quartz geobarometer; Am. Mineral. 73 216-223.

Lal R K and Ackermand D 1979 Coexisting chloritoidstaurolite from the sillimanite (fibrolite) zone, Sini, district Singhbhum, India; Lithos 12 133-142.

Lal R K and Singh J B 1978 Prograde polyphase regional metamorphism and metamorphic reactions in pelitic schists at Sini, district Sighbhum India; N. jb. Miner. Abh. $131304-333$.

Lal R K, Mukerji S and Ackermand D 2005 Barrovian metamorphism of Takdah, Darjeeling (eastern Himalaya); In: Himalaya: Geological aspects (ed.) Saklani P S, 2 529-573.

Le Fort P, Cuney M, Daniel C, France Lanord C, Sheppard S M F, Upreti B N and Videl P 1987 Crustal generation of the Himalayan leucogranites; Tectonophys. 134 39-57.

Mallet F R 1875 On the geology and mineral resources of the Darjeeling district and the western Duars; Geol. Surv. India Memoir 11(I) 1-50.

Mohan A, Windley B F and Searle M P 1989 Geothermobarometry and development of inverted metamorphism in the Darjeeling-Sikkim region of the Eastern Himalaya; J. Metamor. Geol. 1 95-110.

Mukhopadhyay M K and Gangopadhyay P K 1971 Structural characteristics of rocks around Kalimpong, West Bengal; Him. Geol. 1 213-230.

Mukul M 2000 The geometry and kinematics of the Main Boundary Thrust and related neotectonics in the Darjiling Himalayan fold-and-thrust belt, West Bengal, India; J. Struct. Geol. 22 1261-1283.

Newton R C and Haselton H T 1981 Thermodynamics of the garnet-plagioclase- $\mathrm{Al}_{2} \mathrm{SiO}_{5}$-quartz geobarometers; In: Thermodynamics of minerals and melts (eds) Newton R C, Navrotsky A and Wood B J, Adv. Phys. Geochem. (New York: Springer Verlag) 2 129-145.

Perchuk L L 1990 Derivation of thermodynamically consistent system of geothermometers and geobarometers for metamorphic rocks and magmatic rocks; In: Progress in metamorphic and magmatic petrology (ed.) Perchuk L L, Cambridge University Press, pp. 93-112.

Perchuk L L and Lavrent'eva I V 1983 Experimental investigation of exchange equilibria in the system cordieritegarnet-biotite; In: Kinetics and equilibrium in mineral reactions (ed.) Saxena S K, Springer-Verlag, New York, pp. 199-239.

Perchuk L L, Aranovich L Y, Podlesskii K K, Lavrent'eva I V, Gerasimov V Y, Fed'Kin V V, Kitsul V I, Karasakov L P and Berdnikov N V 1985 Precambrian granulites of the Aldan shield, eastern Siberia, USSR; J. Metamor. Geol. 3(3) 265-310.

Powell R and Holland T 1999 Relating formulations of the thermodynamics of mineral solid solutions: Activity modeling of pyroxenes, amphiboles, and micas; Am. Mineral. $841-14$.

Prakash D and Tewari S 2013 Field and textural relationship in pelitic schists and gneisses from the area around Mangpu, Darjeeling district, West Bengal; J. Geol. Soc. India 81 451-454.

Ray S 1947 Zonal metamorphism in Eastern Himalaya and some aspects of local geology; Quart. J. Min. Met. Soc. India 19 117-139.

Rubatto D, Chakraborty S and Dasgupta S 2013 Timescales of crustal melting in the Higher Himalayan crystallines (Sikkim, Eastern Himalaya) inferred from trace elementconstrained monazite and zircon chronology; Contrib. Mineral. Petrol. 165 349-372.

Schreyer W, Abraham K and Behr H J 1975 Sapphirine and associated minerals from the kornerupine rocks and Waldheim, Saxony; N. ZJb. Miner. Abh. 126 1-27.

Sinha Roy S 1974 Polymetamorphism in Daling rocks from a part of Eastern Himalaya and some problems of Himalayan metamorphism; Him. Geol. 4 47-101.

Spear F S, Kohn M J and Cheney J T 1999 P-T paths from anatectic pelites; Contrib. Mineral. Petrol. 134 17-32. 
Thompson A B 1974 Calculation of muscovite-paragonitealkali feldspar phase relation; Contrib. Mineral. Petrol. 44 173-194.

Thompson A B 1976 Mineral reaction in pelitic rocks: I. Prediction of $\mathrm{P}-\mathrm{T}-\mathrm{X}(\mathrm{Fe}-\mathrm{Mg})$ phase relations. II. Calculation of some $\mathrm{P}-\mathrm{T}-\mathrm{X}(\mathrm{Fe}-\mathrm{Mg})$ phase relations; Am. J. Sci. 276 401-454.

Thompson J B and Norton S A 1968 Palaeozoic regional metamorphism in New England and adjacent areas; In: Studies of Appalachian Geology: Northern and Maritime (eds) E-an-Zen, White W S, Hadley J B and Thompson J B Jr, Intersci. Wiley, New York, pp. 319 327.

Tracy R J 1978 High grade metamorphic reactions and partial melting in pelitic schist, west-central Massachusetts; Am. J. Sci. 278 150-178.

Tracy R J, Robinson P and Thompson A B 1976 Garnet composition and zoning in the determination of temperature and pressure of metamorphism, central Massachusetts; Am. Mineral. 61 762-775.
Turner F J 1968 Metamorphic Petrology; McGraw-Hill Book Co., New York.

Turner F J and Verhoogen J 1960 Igneous and Metamorphic Petrology, 2nd edn; McGraw-Hill Book Co., New York.

Wager L R 1939 The Lachi Series of North Sikkim and the age of the rocks forming the Mt. Everest; Rec. Geol. Surv. India 74 171-188.

White R W, Powell R, Holland T J B and Worley B A 2000 The effect of $\mathrm{TiO}_{2}$ and $\mathrm{Fe}_{2} \mathrm{O}_{3}$ on metapelitic assemblages at greenschist and amphibolite facies conditions: Mineral equilibria calculations in the system $\mathrm{K}_{2} \mathrm{O}-\mathrm{FeO}-\mathrm{MgO}-$ $\mathrm{Al}_{2} \mathrm{O}_{3}-\mathrm{SiO}_{2}-\mathrm{H}_{2} \mathrm{O}-\mathrm{TiO}_{2}-\mathrm{Fe}_{2} \mathrm{O}_{3} ;$ J. Metamor. Geol. 18 $497-511$.

White R W, Powell R and Clarke G L 2003 Prograde metamorphic assemblage evolution during partial melting of metasedimentary rocks at low pressures: Migmatites from Mt Stafford, central Australia; J. Metamor. Geol. 44(11) 1937-1960.

Winkler H G F 1978 Petrogenesis of metamorphic rocks; Springer Verlag, New York, 334p. 